\title{
COMPARATIVE STUDY OF THE TOPICAL EFFECTIVENESS OF THE ANDIROBA OIL (Carapa guianensis) AND DEET 50\% AS REPELLENT FOR Aedes sp
}

\author{
Hélio Amante MIOT(1), Rafaelle Fernandes BATISTELLA(1), Khristiani de Almeida BATISTA(1), Dimas Eduardo Carneiro VOLPATO(1), \\ Leonardo Silveira Teixeira AUGUSTO(1), Newton Goulart MADEIRA(2), Vidal HADDAD Jr.(1) \& Luciane Donida Bartoli MIOT(1)
}

\begin{abstract}
SUMMARY
DEET (N,N-diethyl-3-methylbenzamide) is nowadays the most effective mosquito repellent available, however, its use can present some topical and systemic side effects. Some botanical compositions, as Andiroba (Carapa guianensis), have been proved repellent properties at low cost and toxicity. An experimental study was driven involving four volunteers submitting their forearms covered with Andiroba oil at 100\%, DEET 50\%, refined soy oil, Andiroba oil 15\% and in the absence of products, directly to healthy females of Aedes sp. The times of first and third bites were checked. The results showed that the median of the first bite without any product was $17.5 \mathrm{~s}$ and the third bite, 40.0s. In the soy oil, the bites happened in $60.0 \mathrm{~s}$ and $101.5 \mathrm{~s}$, in the presence of Andiroba oil $100 \%$, in 56.0s and 142.5s and in Andiroba oil 15\%, in 63.0s and 97.5s. The volunteers using DEET 50\% had not received bites after 3600s in most of the experiments ( $\mathrm{p}<0.001$ Wilcoxon). Pure Andiroba oil compared to the soy oil, forearm without product and Andiroba oil $15 \%$, showed discreet superiority ( $\mathrm{p}<0.001$ Wilcoxon). Our conclusion is that this study demonstrated that the pure Andiroba oil presents discreet repellent effect against bite of Aedes sp., being significantly inferior to DEET $50 \%$.
\end{abstract}

KEYWORDS: Aedes; Insect repellent; DEET; Andiroba.

\section{INTRODUCTION}

The diseases transmitted by insects continue as the main source of infectious diseases and death for infect-contagious diseases all over the world. Only mosquitoes transmit diseases for more than 700 million people each year ${ }^{6,8}$.

Protection against bites of arthropods is reached avoiding recognized infested areas, knowing the habits and schedules of the insects, dressing protecting clothes and using repellents. In some occasions, the use of repellent is the only measure of possible protection, for an individual, when applied in the skin and in the clothes, or for environmental protection, when liberated in a restrict ambient ${ }^{8}$.

Malaria, dengue, yellow fever, elephantiasis (wuchereriosis), leishmaniasis, some forms of encephalitis, Chagas disease, pemphigus, strophulus and anaphylaxis are examples of diseases that could be prevented with the use of repellent of mosquitos ${ }^{6,7,12}$.

The DEET (N,N-diethyl-3-methylbenzamide) is the most effective and studied repellent available. This substance has an excellent protection profile all over the world after more than 40 years of use, but it can cause toxic reactions (usually if used in incorrect way) ${ }^{6,8}$.
The massive use of DEET in the risk populations for those entities is limited by the cutaneous irritation and toxicity derived of the systemic absorption, mainly in children and pregnant women. Their adverse effects include irritant contact dermatitis, allergic reactions or signs of neurological or cardiovascular toxicity, as ataxy, encephalopathy, hypotension and bradicardy ${ }^{11}$.

DEET can also be removed by the perspiration or rain, and its effectiveness diminished in a significant way in high temperatures. It is also an organic solvent capable to dissolve or to damage plastics, glasses of clocks, glasses frames and some synthetic cloths ${ }^{8}$.

The research for the development of the perfect topic repellent has been a continuous scientific objective for many years, but it still has to be reached. The ideal repellent should repel multiple species of arthropods, to stay effective for, at least, eight hours, not to cause any irritation to the skin or mucous membranes, not to possess any systemic toxicity, to be resistant to the water and the abrasion, and to be no greasy and without odor, in other words, to be cosmetically attractive ${ }^{7}$.

The discovery of botanical compositions derived of plants with repellent properties (as citronella, Andiroba, melissa, geranium, eucalyptus, soy, rosemary among others) woke up the scientific 


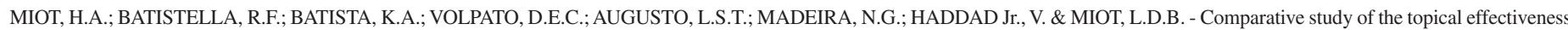
of the andiroba oil (Carapa guianensis) and DEET 50\% as repellent for Aedes sp. Rev. Inst. Med. trop. S. Paulo, 46(5):253-256, 2004.

community's interest for their low cost and toxicity. None of the derived chemists of plants tested up to now demonstrated the wide effectiveness and duration of DEET, but some presented important experimental repellent activities ${ }^{2,4,9}$.

Some studies verified antifeedant properties of the Andiroba (Carapa guianensis) in the candle form, that when burned by 48 hours protects $100 \%$ in closed ambient of up to $27 \pm 10 \mathrm{~m}^{2}$ against bites of Aedes aegypti. Moreover, there is need of more studies about the effect of topical Andiroba as individual protection ${ }^{9}$.

Because of the recent dengue epidemic in Brazil, sanitary authorities are concerned in developing measures of control and prevention of the disease and the development of an effective repellent against the Aedes $\mathrm{sp}$. that can have massive use in the population, without toxicity risk and of low cost, could provide important impact in the casuistry and mortality of the dengue in the country.

This study compares the effectiveness of topical Andiroba oil 100\% on the skin in relation to the lotion of DEET 50\% against bites of Aedes sp.

\section{MATERIALS AND METHODS}

An experimental intervention study, controlled, was accomplished at the Laboratory of Creation of Mosquitoes of the Departamento de Parasitologia at Instituto de Biociências-Universidade Estadual Paulista of Botucatu (São Paulo State, Brazil).

One hundred-twenty healthy adult females of Aedes sp. (Fig. 1) were selected and divided in four transparent nurseries of plastic with 5.5 liters each for the tests.

The mosquitoes were kept alive feed with glucose $5 \%$ solution, with no blood supply for at least $24 \mathrm{~h}$ before experiments and restored periodically in case of loss.

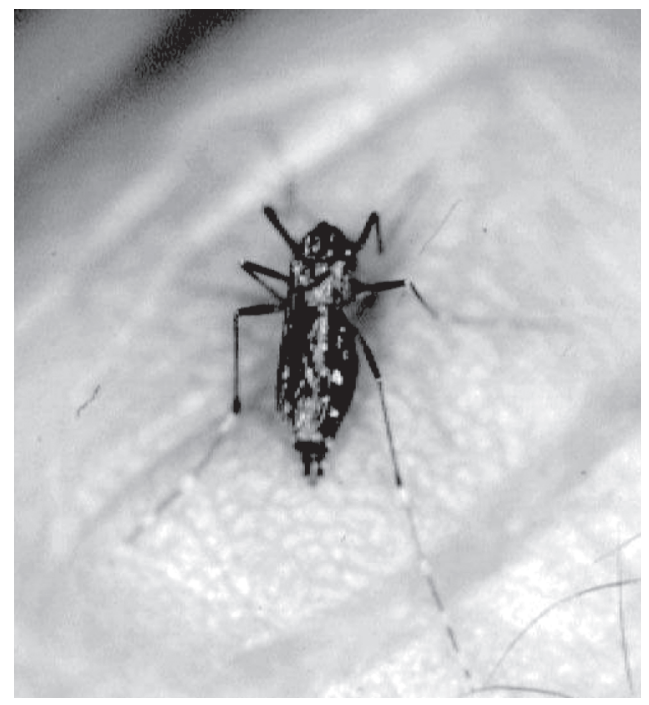

Fig. 1 - Aedes aegypti (adult female).
Four healthy volunteers submitted their forearms, covered or not for the test products, to bites of females of Aedes sp. in five different days. The time until the first and third bites was measured in seconds. The measure was interrupted at the third bite or until the limit of 3600 seconds. The hands and fists were covered by latex gloves (Fig. 2) and the temperature, illumination and humidity of the ambient were maintained constant.

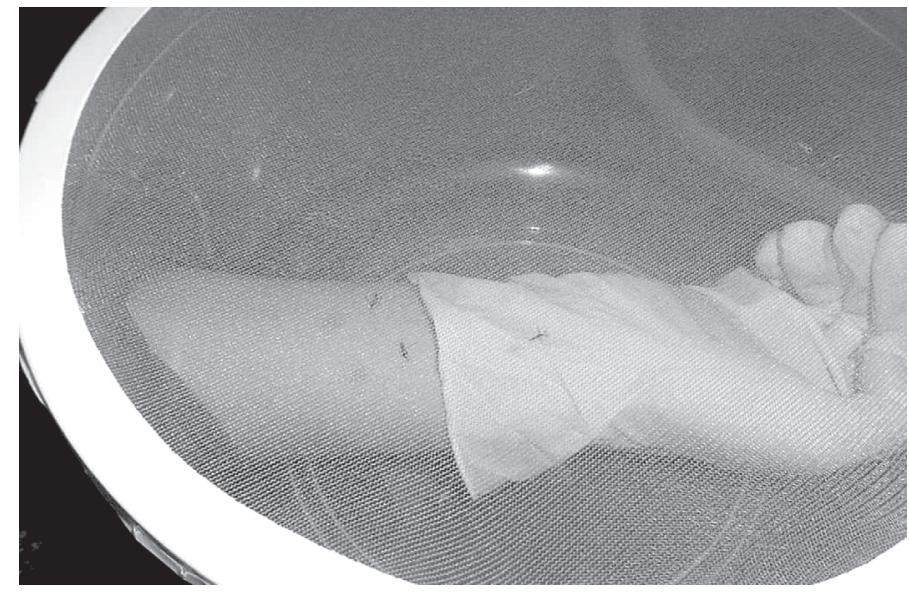

Fig. 2 - Voluntary forearm submitted to bites of Aedes sp.

We tested as negative controls: refined soy oil, Andiroba oil to $15 \%$ and the forearm without products; as positive control lotion of DEET $50 \%$ (Exposis ${ }^{\circledR}$, Osler Laboratory, Brazil); and the substance tests: oil of Andiroba $100 \%$ (manipulation medical drugstore, Brazil).

We still analyzed the results among different volunteers to compare the individual factors of susceptibility to bites. The paired results of each experiment were compared by the Wilcoxon test. The measures of the variability among the volunteers were compared through the KruskalWallis test. Data were tabulated and analyzed through the software Bioestat 2.0 ${ }^{\mathrm{TM}}$, adopted as significant $\mathrm{p}<0.05^{1}$.

\section{RESULTS}

Each volunteer accomplished six experiments comparing pairs of products in each forearm (Fig. 3). The median ( \pm standard deviation) of the first bite in the arm without product was $17.5 \mathrm{~s}( \pm 60.2 \mathrm{~s})$ and the third bite, $40.0 \mathrm{~s}( \pm 92.9 \mathrm{~s})$.

The distributions of the volunteers' measures are showed in the Figure 4 , being verified a significant interpersonal difference $(\mathrm{p}<0.001$ KruskalWallis). With the use of the Soy oil, the first bite happened in $60.0 \mathrm{~s}$ $( \pm 81.0 \mathrm{~s})$ and the third, in $101.5 \mathrm{~s}( \pm 175.5 \mathrm{~s})$.

The use of Andiroba oil 100\% produced the first bite in 56.0s $( \pm 1092.7 \mathrm{~s})$ and the third, in $142.5 \mathrm{~s}( \pm 1264.5 \mathrm{~s})$. With the Andiroba oil $15 \%$, the first bite was in $63.0 \mathrm{~s}( \pm 789.5 \mathrm{~s})$ and the third, in $97.5 \mathrm{~s}$ $( \pm 1296.5 \mathrm{~s})$.

The positive control (DEET 50\%) supplied the first bite in 3600s $( \pm 332.0 \mathrm{~s})$ and the third in $3600 \mathrm{~s}( \pm 227.6 \mathrm{~s})$. In other words, in most of the experiments the mosquitoes did not bite after one hour. 


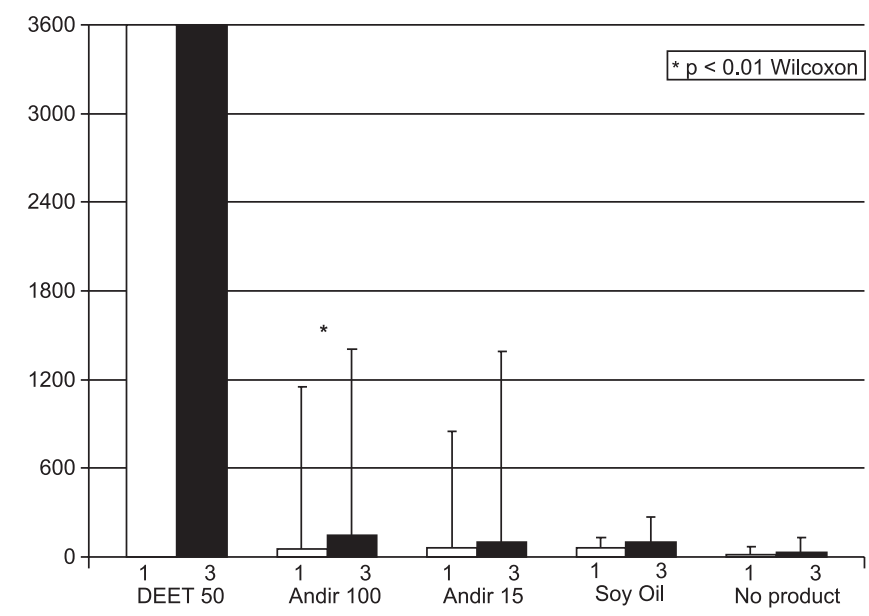

Fig. 3 - Distribution of the times (in seconds) among the first (1) and the third (3) bites of Aedes sp. for diverse products.

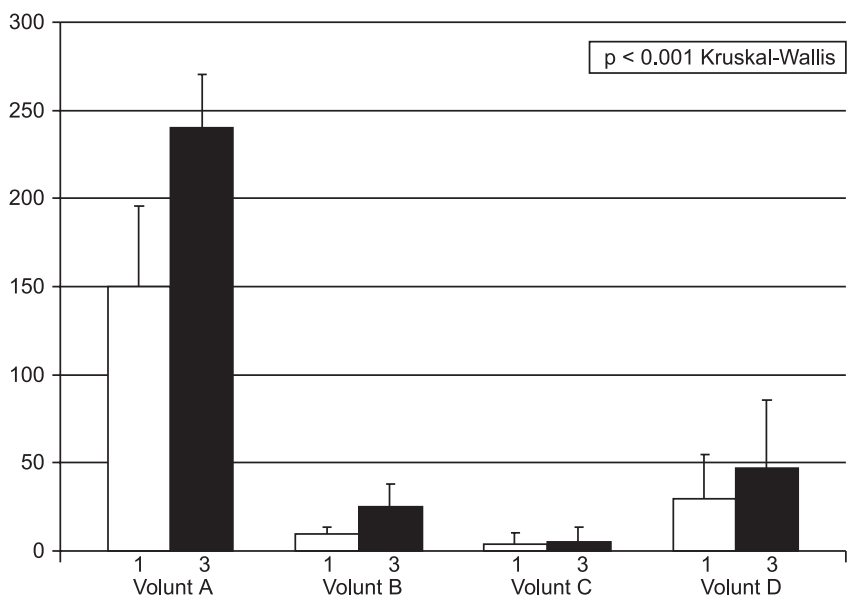

Fig. 4 - Distribution of the times (in seconds), among the volunteers (Volunt A, B, C and D), of the first (1) and the third (3) bites of Aedes sp. in the forearms without any product.

The times of the lotion of DEET 50\% compared with all the other products demonstrated significant superiority ( $p<0.001$ Wilcoxon).

When the Andiroba oil $100 \%$ was tested comparatively to the soy oil, the arm without product and Andiroba oil 15\%, it demonstrated discreet superiority ( $\mathrm{p}<0.001$ Wilcoxon).

We observed the death of some mosquitoes after the introduction of the forearms impregnated by DEET 50\%, inferring a light insecticide action, besides repellent, by DEET.

\section{DISCUSSION}

In spite of the intense research for the development of new repellent of mosquitoes, DEET stays as the most potent, however, maintaining a delicate profile of safety and tolerability for massive use in populations. During this experiment no cutaneous or systemic adverse effects were described by the use of DEET in the forearms, in spite of the notable insecticide odor.
Pure Andiroba oil (100\%) showed a superior profile of repellence compared to the product absence, what reiterates the discoveries of the researches involving the repellence of Andiroba candle. However, its time of repellent effect was remarkably inferior to DEET $50 \%$.

Those positive results, but of low potency, are repeated in studies of other botanical essences as the citronella and the eucalyptus ${ }^{10}$, but as insects are important in the pollination phase of most of the plants, it is unlikely that some vegetable species had survived the natural selection process once their repellent effect, at least in vivo, would be so potent.

No experiment published in the literature, until the present, had told the light insecticide effect of DEET 50\%, such phenomenon called "knock-down" was described just by the use of pyretroids impregnated in the clothes or bed nets 5 .

Several individual and environmental factors are involved in the risk of bites of mosquitoes. Mainly the corporal temperature, exhalation of $\mathrm{CO}_{2}$ and ammonia, presence of skin eczema, percentage of exposed corporal area and exhaled odors; also environment temperature, humid climate, concentration of mosquitoes and alimentary state of the females contribute to insect attraction ${ }^{3,11}$. Such factors of individual susceptibility determine a significant variability in the times of bites among the volunteers, and in different moments they can answer for the great variability among each participant's measures.

The concentration of mosquitoes in the nurseries is quite superior the any conventional situation of the nature (about five mosquitoes for liter of air) what accelerates the time of the bites and it optimizes the experiment, not allowing, however, extrapolating such values for the use in open ambient.

The study demonstrated that the pure Andiroba oil presents discreet repellent effect against bite of Aedes sp., being significantly inferior to DEET $50 \%$.

There was not measured the efficacy of the association of Andiroba and DEET, or the use of Andiroba oil as DEET vehicle with the aim to reduce the concentration and the risk of toxicity of DEET, without lack of its repellence.

There is also a need for more controlled field studies to evaluate the repellent effects of botanical compounds and the epidemiological impact of its use by populations at risk.

\section{RESUMO}

Estudo comparativo da eficácia tópica do óleo de andiroba (Carapa guianensis) e DEET 50\% como repelente para Aedes sp

O DEET (N, N-dietil-3-metilbenzamida) é hoje o repelente mais efetivo disponível, porém, seu uso pode apresentar importantes efeitos colaterais tópicos e sistêmicos. Alguns compostos botânicos, como a Andiroba (Carapa guianensis), têm demonstrado propriedades repelentes a um baixo custo e baixa toxicidade. Quatro voluntários hígidos submeteram seus antebraços recobertos com óleo de Andiroba a 100\%, DEET 50\% (controle positivo), óleo de soja refinado, óleo de Andiroba $15 \%$ e na ausência de produtos (controles negativos), diretamente a 


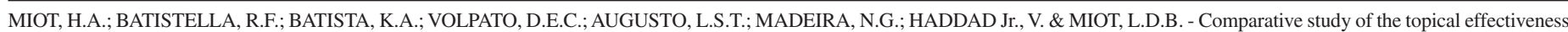
of the andiroba oil (Carapa guianensis) and DEET 50\% as repellent for Aedes sp. Rev. Inst. Med. trop. S. Paulo, 46(5):253-256, 2004.

picadas de fêmeas saudáveis de Aedes sp. Foram aferidos os tempos da primeira e terceira picadas. Os resultados mostraram que a mediana da primeira picada nos antebraços sem produto foi $17.5 \mathrm{~s}$ e a terceira picada, 40.0s. No óleo de soja, as picadas ocorreram em $60.0 \mathrm{~s}$ e $101.5 \mathrm{~s}$. No óleo de Andiroba $100 \%$, em 56.0s e 142.5s. Com Andiroba 15\%, em 63.0s e 97.5s. Usando DEET 50\% não houve picadas após 3600s na maioria dos experimentos ( $\mathrm{p}<0.001$ Wilcoxon). O óleo de Andiroba 100\% comparado ao óleo de soja, antebraço sem produto e óleo de Andiroba $15 \%$, mostrou discreta superioridade ( $p<0.001$ Wilcoxon). Concluímos que o óleo puro de Andiroba apresenta efeito repelente discreto contra picada de Aedes sp., sendo significativamente inferior ao DEET 50\%.

\section{ACKNOWLEDGEMENTS}

The authors are thankful to the editor and referees for important contributions to this paper.

\section{REFERENCES}

1. AYRES, M.; AYRES Jr,, M.; AYRES, D.L. \& SANTOS, A.S. - Bioestat: 2.0 aplicações estatísticas nas áreas das ciências biológicas e médicas. Belém, Sociedade Civil Mamirauá; MCT/CNPq, 2000.

2. BROWN, M. \& HEBERT, A.A. - Insect repellents: an overview. J. Amer. Acad. Derm., 36: 243-249, 1997.

3. CURTIS, C.F. - Fact and fiction in mosquito attraction and repulsion. Parasit. today, 2: 316-318, 1986.
4. DAS, N.G.; BARUAH, I.; TALUKDAR, P.K. et al. - Evaluation of botanicals as repellents against mosquitoes. J. Vector Borne Dis., 40: 49-53, 2003.

5. ENSERINK, M. - What mosquitoes want: secrets of host attraction. Science, 298: 9092, 2002.

6. FRADIN, M.S. - Mosquitoes and mosquito repellents: a clinician's guide. Ann. intern. Med., 128: 931-940, 1998.

7. FRADIN, M.S. - Insect repellents. E-medicine. USA, 2002. (website: http:// www.emedicine.com/derm/topic540.htm). Accessed March 15, 2004.

8. FRADIN, M.S. \& DAY, J.F. - Comparative efficacy of insect repellents against mosquito bites. New Engl. J. Med., 347: 13-18, 2002.

9. GILBERT, B.; TEIXEIRA, D.F.; CARVALHO, E.S. et al. - Activities of the Pharmaceutical Technology Institute of the Oswaldo Cruz Foundation with medicinal, insecticidal and insect repellent plants. An. Acad. bras. Cienc., 71: 265-271, 1999.

10. GIRGENTI, P. \& SUSS, L. - Repellent activity against Aedes aegypti (L.) of formulas based on natural vegetable extracts or synthetic active agents. Ann. Igiene, 14: 205 210,2002

11. MEHR, Z.A.; RUTLEDGE, L.C.; BUESCHER, M.D. et al. - Attraction of mosquitoes to diethyl methylbenzamide and ethyl hexanediol. J. Amer. Mosq. Control Ass., 6: 469-476, 1990.

12. STIBICH, A.S.; CARBONARO, P.A. \& SCHWARTZ, R.A. - Insect bite reactions: an update. Dermatology, 202: 193-197, 2001.

Received: 29 March 2004

Accepted: 16 August 2004 